\title{
PERLINDUNGAN HUKUM BAGI PEMEGANG SANDE BERLAPIS PADA MASYARAKAT HUKUM ADAT BESEMAH DI KOTA PAGAR ALAM
}

\author{
Herma Diana \\ Sekolah Tinggi Ilmu Ekonomi Lembah Dempo, Pagaralam \\ Email : herma.diana.hd@gmail.com \\ Mastriati Hini Hermala Dewi \\ Sekolah Tinggi Ilmu Ekonomi Lembah Dempo, Pagaralam \\ Email : mastriatidewidewi@gmail.com
}

\begin{abstract}
ABSTRAK
Sande Berlapis bagian dari Hukum Gadai Tanah yang masih eksis saat ini di Daerah Besemah di Kota Pagar Alam Provinsi Sumatera Selatan. Adapun yang menjadi objek Sande pada Masyarakat Hukum Adat Besemah di Kota Pagar Alam adalah tanah dan bukan tanah. Sande bagi masyarakat Besemah di Kota Pagar Alam merupakan langkah dalam mengatasi masalah ekonomi tanpa harus takut kehilangan objek Sande dan merupakan budaya pada Masyarakat Hukum Adat Besemah di Kota Pagar Alam. Sande berlapis pada Masyarakat Hukum Adat Besemah di Kota Pagar Alam terjadi atas keinginan pemegang Sande untuk membayar harga kepada pemberi Sande dan mengharuskan pemberi Sande menyerahkan tanahnya kepada pemegang gadai dengan dipenuhinya ketentuan yang berlaku bagi Sande, sementara tanahnya sudah tergadai lebih dahulu kepada pihak lain. Penguasaan benda Sande tidak selamanya harus dikeluarkan dari kekuasaan pemberi Sande, akan tetapi dapat tetap dikuasai oleh pemberi Sande yang disebut dengan Tating Tanpa Kuasa, sedangkan Sande yang objeknya harus dikeluarkan dari pemegang Sande disebut Tating Kuasa.

Tating tanpa kuasa ini merupakan salah satu karakter khas lembaga Sande pada Masyarakat Hukum Adat Besemah di Kota Pagar Alam sehingga penjual Sande dapat menggadaikan kembali tanahnya baik dengan persetujuan maupun tanpa persetujuan pembeli Sande. Oleh karena itu perlu dilakukan penelitian tentang Perlindungan Hukum Pemegang Sande Berlapis Pada Masyarakat Hukum Adat Besemah di Kota Pagar Alam yang masih berlangsungpada saat ini. Tim peneliti melakukan penelitian hukum empiris dengan pendekatan budaya/ etnografi approachdan pngumpulan data melalui wawancara dan observasi dengan menggunakan Purposive Sampling dan Snow Ball.
\end{abstract}

Kata Kunci : Hukum adat bersemah,Sande, Masyarakat Bersemah

\section{PENDAHULUAN}

\subsection{Latar Belakang}

Perjanjian gadai menurut Hukum

Adat, memandang gadai (tanah) sebagai hak yang memberikan kewajiban bukan karena adanya perjanjian pinjaman. Meminjam uang dan perbuatan hukum lainnya menimbulkan utang piutang, Pemegang gadai berhak memungut hasil yang ditimbulkan oleh dan dari tanahnya menjadi hak pemegang gadai yang merupakan bunga dari utang tersebut.
Sampai gadai tersebut ditebus oleh pemberi gadai.

Pada masyarakat Besemah di Kota Pagar Alam gadai tanah adat disebut dengan istilah "sande" yaitu suatu bentuk perjanjian yang menyebabkan tanahnya diserahkan kepada orang lain untuk menerimah sejumlah uang tunai dengan persetujuan pemberi gadai dapat menebus kembali sedangkan pemegang gadai berhak menikmati hasil tanah sampai 
ditebus kembali tanah tersebut dari pemegang gadai.

Faktor pendorong sande pada masyarakat Besemah di Kota Pagar Alam, umumnya karena kebutuhan ekonomi dan terjadi pada masyarakat golongan menengah kebawa. Hampir 50\% dari masyarakat menengah ke bawah yang mempunyai lahan pertanahan pernah melakukan sande khususnya meraka yang memiliki anak yang masih sekolah dan tidak ada pekerjaan sambilan kecuali bertani. Selain karena kebutuhan ekonomi, proses sande sangat mudah sehingga tidak membutuhkan waktu yang lama untuk memperoleh sejumlah uang, selain itu juga sande dianggap sangat aman bagi kedua belah pihak karena sande adalah salah satu cara menyelesaikan kesulitan keuangan tanpa harus takut kehilangan objek sande karena ketidakmampuan menebus karena dalam Masyarakat Hukum Adat Besemah di Kota Pagar Alam sande tidak terikat jangka waktu sehingga bisa berlangsung selama mungkin dan dapat diteruskan oleh ahli warisnya.

Bentuk dan proses terjadinya sande, pada masyarakat Besemah di Kota Pagar Alam bentuk sande dapat diklasifikasikan menjadi 2 (dua) yaitu; tertulis tertulis (lisan) dan tertulis. sande secara lisan sangat mudah dan cepat cukup dengan kesepakatan kedua belah pihak tentang harga sande dan obyek sande kemudian dilakukan pembayaran dan penyerahan tanah disaksikan oleh pemilik tanah yang berbatasan dengan objek sande, maka terjadilah sande begitu juga dengan sande yang tetulis, kesepakatan antara kedua belah pihak dituangkan dalam bentuk tulisan dalam kertas bermaterai kemudian ditandatangani oleh kedua belah pihak dan saksi- saksi dan kadang kalah di lakukan dihadapan aparat desa atau tetua adat setempat untuk mendapatkan perlindungan hukum, selanjutnya terjadilah sande.

Dalam Hukum Adat gadai merupakan perjanjian yang mandiri meliputi benda bergerak maupun benda tidak bergerak , artinya semua benda dapat menjadi objek gadai. Pada masyarakat Besemah di Kota Pagar Alam semua benda dapat dijadikan objek sande meskipun pada umumnya masyarakat hanya menggadaikantanah pertanian dan perkebunan. Berbeda dengan gadai Hukum Agraria nasional objek gadai hanyalah benda bergerak sedangkan benda tetap dijaminkan dengan hipotek atau hak tanggungan.

Selain perbedaan itu juga dalam gadai tanah dalam arti sande pada masyarakat adat Besemah di Kota Pagar Alam, sande tidak terikat jangka waktu, hal ini juga membedakan dengan gadai dalam Hukum Nasional kita. Banyak kritikan dari masyarakat menyangkut jangka waktu karena dilihat dari jangka waktu gadai, sebenarnya gadai ( sande) sangat merugikan pihak pemberi gadai hal itu disebabkan banyaknya masyarakat yang tidak mampu menebus gadai sehingga gadai akan berjalan seumur hidup bahkan sampai ke ahli warisnya. Ini merupakan masalah besar bagi pemberi gadai sehubungan dengan kemampuannya membayar uang gadai atau sande meskipun demikinan masyarakat lebih memilih gadai Hukum Adat ketimbang gadai menurut Hukum Nasional. Hal itu disebabkan karena gadai Hukum Agraria nasional prosedurnya berbelit- belit dan formal, sedangkan prosedur gadai Hukum Adat (sande) pada masyarakat Besemah di Kota Pagar Alam jauh lebih mudah dan tidak formal selain itu terpenuhinya 
kebutuhan masyarakat dengan cepat tanpa harus menunggu lebih lama.

Namun begitu, di era globalisasi diharapkan Indonesia mampu membina dan meperhatikan Hukum Adat sebagai suatu sistem yang memenuhi kebutuhan masyarakat dengan mereformasi sistem hukum yang berasal dari bangsa jajahan atau sistem hukum yang dianggap sudah tidak layak lagi agar sistem hukum tersebut bisa memberikan perlindungan dan kepastian hukum kepada masyarakat, diantara dengan adanya Pasal 33 (ayat 3) UUD 1945 yang bertujuan untuk menjamin kepastian hukum .

Dalam UUD 1945 Pasal 33 (ayat 3) dinyatakan bahwa, bumi, air dan kekayaan alam yang terkandung didalamnya dikuasai oleh Negara dan dipergunakan sebesar-besarnya untuk kemakmuran rakyat. Demikian juga dalam UUPA, bahwa seluruh tanah dikuasai oleh Negara, dikuasai Negara berarti Negara sebagai organisasi kekuasaan mempunyai wewenang sebagaimana dijelaskan dalam penjelasan Pasal 33 ayat 3 undang-undang dasar 1945, sebagai berikut :

1. Mengatur serta menyelenggarakan peruntukan, penggunaan, persediaan dan pemeliharaan;

2. Menentukan dan mengatur hak-hak penggunaan atas manfaat dari bumi, air, dan ruang angkasa;

3. Menentukan dan mengatur hubungan hukum antara orang-orang dan perbuatan-perbuatannya terhadap bumi, air dan ruang angkasa.

Memenuhi kebutuhan hidup dan memberikan nafkah adalah kewajiban bagi setiap manusia pada Masyarakat Hukum Adat Besemah di Kota Pagar Alam. Untuk memenuhi kebutuhan hidup tersebut dapat dilakukan dengan cara menggadaikan tanah atau sande ( terjadi hubungan hukum antara pemberi sande dengan pemegang sande). Hanya saja sande pada Masyarakat Hukum Adat Besemah di Kota Pagar Alam belum menjamin kepastian hukum itu sebabnya diperlukan peraturan mengenai gadai tanah (sande) yang terjadi secara adat. Oleh karena itu undangundang perlu mengadakan perubahan sande yang mengandung unsur pemerasan, ini dapat dilihatdalam Pasal 53 UndangUndang Nomor 56/Prp/1960 dan Masyarakat Hukum Adat sendiri sedikit demi sedikit mengendaki perubahan.

Dalam rangka mewujudkan perlindungan itu perlu pengkajian untuk pengakuan dan perlindungan Konstruksi hukum, Proses dan Karakter Hukum Lembaga Gadai tanah (Sande) Pada Masyarakat Hukum Adat Besemah di Kota Pagar Alam. Berdasarkan hal tersebut di atas Penulis tertarik untuk meneliti permasalahan ini ke dalam Penelitian ini dengan judul “ Perlindungan Hukum Bagi Pemegang Sande Berlapis Pada Masyarakat Hukum Adat Besemah Di Kota Pagar Alam."

\subsection{Rumusan Masalah}

Permasalahan yang dibahas sehubungan dengan Perlindungan Hukum Bagi Pemegang Sande Berlapis Pada Masyarakat Hukum Adat Besemah Di Kota Pagar Alam dirumuskan dalam pertanyaan hukum berikut ini :

1. Bagaimanakah proses hukum terjadinya Sande pada Masyarakat Hukum Adat Besemah di Kota Pagar Alam?

2. Bagaimana perlindungan hukum bagi pemegang Sande Berlapis pada Masyarakat Hukum Adat Besemah di Kota Pagar Alam menurut Hukum Agraria yang berlaku saat ini di Indonesia?

3. 


\subsection{Manfaat Penelitian}

Penelitian ini diharapkan dapat memberikan manfaat atau kegunaan yakni sebagai berikut :

1. Dari segi teoritis, hasil penelitian ini diharapkan memberi manfaat bagi perkembangan ilmu Hukum Adat, khususnya hukum gadai tanah yang mempunyai keterkaitan dengan hukum gadai menurut hukum positif tetulis baik hukum jaminan maupun Hukum Agrarian nasional.

2. Dari segi praktis, hasil penelitian ini diharapkan bermanfaat sebagai bahan masukan dan sumber informaasi bagi pihak - pihak yang terlibat dalam pelaksanaan gadai tanah pada Masyarakat Hukum Adat Besemah di kota Pagar Alam.

3. Bagi warga Masyarakat Hukum Adat sebagai pedoman dalam pelaksanaan gadai yang berkaitan dengan gadai tanah.

4. Bagi pemuka adat sebagai pedoman dalam mengambil keputusan Hukum Adat yang berkaitan dengan gadai tanah.

5. Pemerintah Indonesia dalam hal ini dalam hal ini Badan Pertanahan Nasional sebagai bahan masukan dan informasi dalam kaitannya dengan pengakuan dan perlindungan tentang gadai tanah adat pada Masyarakat Hukum Adat Besemah di Kota Pagar Alam.

\subsection{Tujuan penelitian}

Adapun tujuan dari penelitian ini meliputi :

a. Untuk mendiskripsikan Perlindungan Hukum Bagi Pemegang Sande Berlapis Pada Masyarakat Hukum Adat Besemah Di Kota Pagar Alam pada Masyarakat Hukum Adat Besemah di Kota Pagar Alam. b. Untuk diskripsikan ada tidaknya perlindungan hukum terhadap Bagi Pemegang Sande Berlapis Pada Masyarakat Hukum Adat Besemah Di Kota Pagaralam Pada Masyarakat Hukum Adat Besemah di Kota Pagar Alam menurut Hukum Nasional yang berlaku saat ini Indonesia.

\section{TINJAUAN PUSTAKA}

\subsection{Konsep Hukum Adat}

Istilah Hukum Adat Hukum adalah seperangkat norma dan aturan adat atau kebiasaan yang berlaku di suatu wilayah. Istilah "kebiasaan" adalah terjemahan dari bahasa Belanda "gewoonte recht, " sedangkan istilah "adat" berasal dari istilah Arab yaitu "adah" yang berarti juga kebiasaan. Jadi istilah kebiasaan dan istilah adat mempunyai arti yang sama yaitu kebiasaan. (Rato, 2011 :4)

Dalam perkembangannya, Hukum Adat mengandung dua arti yaitu :

1) Hukum kebiasaan yang bersifat tradisional disebut juga Hukum Adat.Adalah hukum yang dipertahankan dan berlaku di lingkungan Masyarakat Hukum Adat tertentu.

Contoh : Hukum Adat Batak, Hukum Adat Jawa, dll.

2) Hukum kebiasaan.

Adalah hukum yang berlaku dalam kehidupan masyarakat, dalam hubungan pergaulan antara yang satu dan yang lain, dalam lembaga-lembaga masyarakat dan dalam lembaga-lembaga kenegaraan, kesemuanya yang tidak tertulis dalam bentuk perundangan. (Soejono, 2011 :72)

Menurut Supomo \& Hazairin: mengambil kesimpulan bahwa Hukum Adat adalah hukum yang mengatur tingkah laku manusia Indonesia dalam hubungan satu sama lain, baik yang merupakan 
keseluruhan kelaziman, kebiasaan dan kesusilaan yang benar-benar hidup di masyarakat adat karena dianut dan dipertahankan oleh anggota-anggota masyarakat itu, maupun yang merupakan keseluruhan peraturan yang mengenal sanksi atas pelanggaran dan yang ditetapkan dalam keputusan-keputusan para penguasa adat. (mereka yang mempunyai kewibawaan dan berkuasa memberi keputusan dalam masyarakat adat itu) yaitu dalam keputusan lurah, penghulu, pembantu lurah, wali tanah, kepala adat, hakim.

Bushar Muhammad menjelaskan bahwa untuk memberikan definisi hukum ada sulit sekali karena, Hukum Adat masih dalam pertumbuhan; sifat dan pembawaan Hukum Adat ialah:

a. Tertulis atau tidak tertulis;

b. Pasti atau tidak pasti;

c. Hukum raja atau hukum rakyat dan sebagainya

\subsection{Gadai Tanah}

\section{Pengertian Gadai Tanah}

Pengertian hak gadai menurut Hukum Agraria nasional adalah seperti yang disebutkan dalam penjelasan umum Undang-Undang Nomor 56 Prp Tahun 1960 angka 9a yang berbunyi sebagai berikut:

Yang dimaksud dengan gadai ialah hubungan antara seseorang dengan tanah kepunyaan orang lain yang mempunyai utang uang kepadanya, selama utang tersebut belum dibayar lunas maka tanah itu tetap berada dalam penguasaan yang meminjamkan uang tadi (pemegang gadai) selama itu pula hasil tanah seluruhnya menjadi hak pemegang gadai yang dengan demikian merupakan bunga dari utang uang tersebut. (UU No. 56 1960)

\section{Dasar Hukum Gadai Tanah}

Pasal 53 UU No. 56/Prp/1960 Tentang Penetapan Luas Tanah Pertanian, mengamatkan hak gadai sebagai hak yang bersifat sementara diupayakan untuk dihapus dalam waktu yang singkat sebagai tindak lanjut dari Pasal 7 Undang- Undang Nomor 56/Prp/1960 Tentang Penetapan Luas Tanah Pertanian, yang bertujuan untuk menghapus transaksi gadai tanah yang berdasarkan Hukum Adat Indonesia, namun lembaga peradilan di dalam penerapannya masih tidak konsisten sehingga menimbulkan adanya dualisme, yaitu gadai tanah berdasarkan Hukum Agraria nasional dan Hukum Adat sehingga menimbulkan ketidakpastian perlindungan hukum.

3. Hak dan Kewajiban Para Pihak dalam Perjanjian Gadai Tanah

\section{a. Pemberi gadai}

1. Setelah menerima uang gadai, maka segera tanah yang digadaikan itu diserahkan kepada pihak yang member uang atau disebut dengan pemegang gadai.

2. Pemberi gadai dapat sewaktu-waktu menebus tanah dengan syarat pemegang gadai sudah memetik hasilnya (panen) paling sedikit satu kali.

3. Jika tanah yang digadaikan musnah, pemberi gadai tidak dapat dituntut untuk mengembalikan uang gadai yang telah terima.

4. Jika ada perbedaan nilai uang pada waktu menggadaikan dan menebus, maka harus menanggung risiko bersama- sama dengan pemegang gadai.

\section{b. Pemegang Gadai}

1) Setelah membayar uang gadai, maka pemegang gadai menguasai tanah gadai terasebut, untuk dipelihara dan berhak pula mnegunakan serta memungut hasinya. 
2) Apabila sewaktu-waktu pemegang gadai ini membutuhkan uang, maka berhak melakukan pendalaman gadai dengan seizin pemilik tanah atau menganakkan gadai jika tanpa seizing pemilk tanah.

3) Jika tanah tersebut musnah karena bencana alam, misalnya banjir maka pemegang gadai tidak boleh menuntut kembali uang gadainya.

4) Wajib mengembalikan tanah gadai tersebut, setelah dikuasai selama 7 ( tujuh) Tahun, dan jika tidak sampai 7 ( tujuh) Tahun maka pengembalian uang gadai dihitung dengan ketentuan : 7 1/2 - masa berlangsungnya hak gadai) $\mathrm{x}$ uang gadai

5) Dalam perjanjian gadai yang disertai dengan perjanjian, dalam jangka waktu yang ditentukan pemberi gadai tidak dapat menebus kembali tanahnya, maka dengan perantaraan pengadilan negeri barulah pemegang gadai dapat memiliki tanah gadai tersebut sesuai dengan perjanjian, jika perlu dengan menambah uang lagi sesuai dengan harga tanah jika di jual lepas . (Istoqomah : 93)

\section{MOTODOLOGI PENELITIAN}

\subsection{Jenis Penelitian}

Penelitian ini adalah jenis penelitian hukum case study ( studi kasus). Penelitian ini memusatkan diri secara intensif dan mendatail pada satu subyek tertentu yang mempelajarinya sebagai suatu kasus. Penelitian hukum case study ini bersifat mendalam dan mendatail yang umumnya menghasilkan gambaran "longitudinal" yakni hasil pengumpulan dan dianalisis kasus dalam jangka waktu tertentu, kasus dapat terbatas pada satu orang, satu lembaga, satu keluarga, satu pristiwa, satu desa ataupun satu kelompok manusia dan kelompok objek lain yang cukup terbatas sebagai satu kesatuan. Fakta-fakta yang dari studi kasus diteliti guna memperoleh data yang akurat dan dapat dipertangung jawabkan mengenai perlindungan hukum pemegang sande berlapis Pada Masyarakat Hukum Adat Besemah di Kota Pagar Alam.

\subsection{Lokasi Penelitian}

Lokasi yang dijadikan tempat penelitian adalah daerah Besemah Kecamatan Dempo Utara di Kota Pagar Alam, Sumatera Selatan.

\subsection{Teknik Pengumpulan Data}

Teknik pengumpulan data dalam penelitian ini menggunakan dua cara pengumpulan data, yaitu ;

1) Studi Lapangan (field research)

Studi lapangan dilakukan dengan cara:

a. Wawancara Pribadi (personal interviewing) yaitu "percakapan dua arah atas inisiatif pewawancara untuk memperoleh informasi dari responden." Wawancara dilakukan secara terbuka dengan menggunakan daftar pertanyaan.

b. Observasi langsung terhadap kondisi di lapangan dengan tujuan untuk mengetahui kondisi yang sesungguhnya secara mendalam.

2) Studi Kepustakaan (library research)

Studi kepustakaan ini dilakukan dengan maksud memperoleh data skunder yaitu dengan melalui serangkaian kegiatan membaca, mengutif, mencatat buku-buku, menelaah peraturan perundang- undangan yang berkaitan dengan permasalahan yang diteliti dalam penelitian ini.

\subsection{Teknik Analisis Data}

Analisis data dalam penelitian ini menggunakan analisis kualitatif, yaitu "dengan cara menguraikan data secara bermutu dalam bentuk kalimat yang teratur, runtun dan tidak tumpang tindih serta efektif sehingga mempermudah 
pemahaman dan interprestasi data."(Winarno, 1989 :143) Analisis kualitatif ini yang digunakan untuk menganalisis fenomena di lapangan mengenai Perlindungan Hukum Bagi Pemegang Sande Berlapis Pada Masyarakat Hukum Adat Besemah Di Kota Pagaralam Pada Masyarakat Hukum Adat Besemah di Kota Pagar Alam sehingga mudah dipahami.

\section{PEMBAHASAN}

\subsection{Sande}

Hasil wawancara dengan bapak, Rusi Siruadi dapat diketahui bahwa sande dalam Masyarakat Hukum Adat Besemah berlaku secara turun menurun, artina selama sande belum ditebus maka sande dapat diwariskan kepada anak cucu mereka. sande Hukum Adat bersifat mendasar, bahwa perjanjian bentuk apapun dalam Hukum Adat bertitik tolak pada dasar kejiwaan, kekeluargaan serta tolong menolong yang selaras dengan perilaku masyarakat ndonesia yang senantiasa mengutamakan kerjasama, gotong royong dan keperdulian terhadap sesama. (Hasil Wawancara dengan Bapak Banuah Petua, 27 Agustus 2018)

\subsection{Objek sande}

Dari hasil wawancara dengan responden obyek sande antara lain; sawah, kebun, pekarangan, emas atau barangbarang berharga lainnya akan tetapi yang lazin terjadi pada masyarakat Besemah adalah sawah dan kebun, dimana sawah menjadi primadona bagi para pemegang sande hal itu disebabkan karena sawah bisa panen 1 tahun $2 \mathrm{x}$ atau lebih sedangkan kebun hanya panen 1 (satu) kali dalam setahun. Hasil wawancara dengan responden diketahui $60 \%$ pemegang sande memilih objek adalah sawah, $30 \%$ kebun dan 10\% Pekarangan.

\subsection{Diskripsi Jenis Sande}

Hasil jawaban dari wawancara dengan responden dapat diketahui, jenis sande ada 2 macam yaitu : sande tating kuase ( sande dengan menerahkan objek sande kepada pemegang sande) dan sande tating tanpa kuase ( sande dimana objek sande tetap dikuasai oleh pemberi sande dengan sistem bagi hasil), sande tating kuase terjadi apabila nilai dari sande dalam jumlah yang besar sedangan sande tating tanpa kuasa nilai sandenya dalam jumlah yang kecil dari hasil wawaancara dengan para responden dapat dikatahui masyarakat yang mengandekan harta dengan cara tating kuase dan tating tanpa kuase dapat dapat diketahui sande dengan sistem tating kuase sebanyak $75 \%$ sedangkan tating tanpa kuase hanya 25\%. (Hasil Wawancara Bapak Darussalam 28 Agustus)

\subsection{Diskripsi Jangka Waktu Sande}

Hasil wawancara pada Masyarakat Hukum Adat Besemah jangka waktu sande sesuai dengan kesepakatan, sawah minimal untuk 4 kali panen, 2 kali panen untuk kebun sedangkan untuk pekarangan minimal 4 kali panen juga atau dalam kurun waktu 2 tahun dan dapat diperpanjang kembali, namun pada praktiknya sande pada masyarakat Besemah tidak ada jangka waktunya selama pemberi sande belum mampu menebus maka sande akan tetap berlangsung.(Hasil WawancaraRusi Suriadi 28 Agustus)

\subsection{Diskripsi pemindahan/pengoperan sande}

Hasil wawancara dengan responden dapat diketahui bahwa sande dapat dipindatangankan/ dioperkan pada pihak ketiga harus sepengetahuan pihak pemegang pihak pemegang sande selama jangka waktu yang diperjanjikan belum berakhir. Pemindatanganan sande dapat 
terjadi kerena keinginan pemberi sande ataupun pemegang sande, dalam hal waktu sande belum berakhir pengoperan terjadi oleh pemberi sande disebabkan karena pemberi sande membutuhkan uang sehingga meminta tambahan uang sande dalam hal pemegang sande mampu menambah jumlah uang sande maka sande akan tetap berlangsung dengan penambahan klausa dalam perjanjian penambahan jumlah uang sande, jika pemegang sande tidak mampu menambah uang sande maka pihak pemberi sande dapat mengoperkan kepada pihak ketiga.

Dalam hal pengoperan dilakukan dari pemberi sande maka pemberi sande harus memberitahukan kepada pihak pemegang sande. Sedangkan pengoperan oleh pihak pemegang sande disebabkan karena pemegang sande menghendaki uang sandenya segera kembali sedangkan jangka waktu sande belum berakhir, dalam hal demikian pemegang sande memberitahukan pemberi sande untuk memindahtangankan/ mengoperkan sande pada pihak ketiga, baik dilakukan oleh pihak pemberi sande ataupun oleh pihak pemegang sande.(Hasil Wawancara Ansori Darussalam 28 Agustus)

\subsection{Diskripsi Berakhiryna Sande Berlapis}

Hasil wawancara berakhirnya sande berlapis yaitu dengan cara menebus kembali semua uang sande kepada para pemegang sande dalam hal pemberi sande tidak mampu menebus kembali uang sandenya maka para pemegang sande dapat menuntut untuk pihak pemebri sande dengan cara kekeluargaan terlebih dahulu apabila langkah ini tidak dicapai kata sepakat maka bisa melalui jalur hukum.(Hasil Wawancara Ahmad Banan 4September 2018)

\subsection{Diskripsi Perlindungan Hukum Pemegang Sande Berlapis}

Hasil wawancara dengen responden untuk mendapatkan perlindungan hukum bagi pemegang sande berlapis agak sulit hal itu dikerenakan sande tersebut dilakukan dengan cara dibawa tangan yang hanya melibatkan saksi-saksi tanpa pejabat yang berwenenang apalagi untuk kasus-kasus sande yang dilakukan secara lisan. Hasil wawancara dapat diketahui bahwa untuk mendapatkan perlindungan hukum bahwa seorang pemegang sande harus mempunai alat bukti berupa surat perjanjian yang mereka sepakati bersama dan dibuat secara tertulis serta dilegalkan oleh aparat setempat minimal kepala desa diikuti oleh para saksi-saksi, di tandatangani oleh kedua belah pihak, aparat desa dan saksisaksi.

\subsection{Diskripsi Perlindungan Hukum Pemegang Sande Berlapis}

Hasil wawancara dengen responden untuk mendapatkan perlindungan hukum bagi pemegang sande berlapis agak sulit hal itu dikerenakan sande tersebut dilakukan dengan cara dibawa tangan yang hanya melibatkan saksi-saksi tanpa pejabat yang berwenenang apalagi untuk kasus-kasus sande yang dilakukan secara lisan. Hasil wawancara dapat diketahui bahwa untuk mendapatkan perlindungan hukum bahwa seorang pemegang sande harus mempunai alat bukti berupa surat perjanjian yang mereka sepakati bersama dan dibuat secara tertulis serta dilegalkan oleh aparat setempat minimal kepala desa diikuti oleh para saksi-saksi, di tandatangani oleh kedua belah pihak, aparat desa dan saksisaksi. 


\section{KESIMPULAN DAN SARAN}

\subsection{Kesimpulan}

1. Proses hukum terjadinya Sande pada Masyarakat Hukum Adat Besemah di Kota Pagar Alam pada Masyarakat Hukum Adat Besemah di Kota Pagar Alam, yaitu sande terjadi dengan perjanjian kedua belah pihak untuk menyerahkan tanahnya kepada pemegang gadai, dan mengharuskan pemberi sande membayar sejumlah uang gadai kepada pemberi sande berdasarkan asas kekeluargaan dan tolong menolong, sehingga obyek gadai tanah (sande) tidak harus dikeluarkan dari kekuasaan pemberi gadai hanya saja status pemberi gadai berubah dari pemilik menjadi menggarap dengan sistem bagi hasil. Selain itu, dalam Masyarakat Hukum Adat Besemah di Kota Pagar Alam berakhir gadai tanah (sande) karena pembayaran uang gadai kepada pemberi gadai bukan karena berakhir jangka waktunya.

2. Perlindungan hukum pemegang sande berdasarkan Hukum Agraria nasional yang berlaku saat ini apabila pemegang sande berlapis tidak mengetahui bahwa obyek sande tersebut telah disandekan maka pemegang sande berlapis dilindungi oleh undang-undang sebaliknya jika pemegang sande berlapis yang mengetahui bahwa objek sande tersebut telah disandekan tetapi masih mau menerima sande dalam arti ada etikat tidak baik dari pemegang sande berlapis maka pemegang sande berlapis tidak dilindungi.

\subsection{Saran}

1. Khususnya untuk pemangku adat agar mensosialisasikan konstruksi dan proses hukum gadai tanah (sande) kepada masyarakat agar masyarakat mengetahui hak dan kewajiban pemegang sande dan pemberi sande.

2. Kepada masyarakat hendaknya gadai tanah (sande) tetap dipertahankan ciri khasnya sebagai budaya daerah menjunjung tinggi asas kekeluargaan dan tolong menolong, sehingga ketika masyarakat menggadaikan tanahnya masyarkat benar-benar akan tertolong.

3. Kepada para pihak untuk mendapatkan pengakuan dan perlindungan gadai tanah (sande) seharusnya membuat perjanjian dalam bentuk tertulis dan dilakukan di hadapan pemuka adat/pejabat desa/pamong desa serta mensosialisasikan arti pentingnya gadai dibuat secara tertulis, karena berfungsi alat bukti telah terjadi gadai dan mempunyai kepastian hukum. Hal tersebut agar gadai tersebut diakui oleh negara dan dilindungi sebagai asset daerah negara bahkan negara terhadap warisan budaya dan adat istiadat yang merupakan sumber budaya nasional, khususnya gadai tanah (sande) pada Masyarakat Hukum Adat Besemah di Kota Pagar Alam.

4. Kantor pertanahan nasional kota pagar Alam hendakna mensosialisasikan ketentuan ang terdapat dalam Pasal 7 UUPA agar gadai tidak mengandung unsur pemerasan/ ekspoloitasi sehingga gadai yang merugikan dan mengandung unsur pemerasan pada Masyarakat Hukum Adat Besemah bisa dihapuskan dan beralih pada gadai agraria nasional.

5. Pemerintah Kota Pagar Alam, sebaiknya membentuk Perda tersendiri mengenai perlindungan dan pengakuan gadai tanah (sande) pada Masyarakat Hukum Adat Besemah di KotaPagarAlam. 


\section{DAFTAR PUSTAKA}

Ahmadi Mirudan Sakka Pati, Hukum Perikatan, Raja Grafindo Persada, Jakarta,2008

Albar. S. Sabari Dkk, PokokPokokHukumAdat, Unsri, 2010

Bernard L. Tanya dkk, TeoriHukum, Strategi Tertib Manusia Linta sRuang Dan Generasi, Genta Publishing, 2010

Gunawan Winadi, Reforma Agraria Perjalanan Yang Belum Berakhir, Insist Prees,Kpa Dan Pustaka Belajar, Bekasi, 2009 Prenada Media Grop, Jakarta 2010.

HerlienBudiono, Asas Keseimbangan bagi Hukum Perjanjian Indonesia: Hukum Perjanjian Berlandaskan Asas-asas Wigati Indonesia, Citra Aditya Bakti, Bandung, 2006.

Iman Sudiyat, Hukum Adat Sketsa Asas, Liberty, Yogyakarta, 1981, Hlm 28.

Kasmir, Bank Dan Lembaga Keuangan Lainnya, Edisi Rivisi, Rajawali Pers, 2008

Khaidir Ali, Yurisprudensi Indonesia Tentang Hukum Agraria, Bina Cipta Hlm 173
Mastriati Hini Herala Dewi, Penelitian, Konstruksi Embaga LSande Sebagai Wujud Gadai Tanah Pada Masyarakat Hukum Adat Besemah Kota Pagar Alam, 2016

M.Koesnoe, Hukum Adat Sebagai Suatu Model Hukum, 1992.: PT. Mandar Maju Bandung,

M. Erwen dan Amrullah Arpan, Filsafat Hukum Mencari Hakikat Hukum, Unsri, Edisi Revisi, Cetakan Kedua 2008.

Rahmadi Usman, Hukum Jaminan Keperdataan, Sinar Grafika, Jakarta,2008

Soemarsono dalam Liliek Istiqama, 1982, Hak-Hak Gadai Atas Tanah Setelah Berlakunya Hukum Agrarian Nasional, Surabaya: Usana Offset.

Ter Haar Bzn.1976.Asas-Asas dan Susunan Hukum Adat. Jakarta:Rradnya Paramita

Urip Santoso,2008. Hukum Agraria dan Hak - Hak Atas Tanah, Jakarta :Kencana Prenada Media Group

Zainuddin Ali,2011. Metode Penelitian Hukum, Jakarta :Sinar Grafika 